\title{
Mobile Energy Laboratory Use Plan
}

\section{April 1989}

Prepared for the

U.S. Department of Energy

Federal Energy Management Program

under Contract DE-AC06-76RLO 1830

Pacific Northwest Laboratory

Operated for the U.S. Department of Energy

by Battelle Memorial Institute 


\section{DISCLAIMER}

This report was prepared as an account of work sponsored by an agency of the United States Government. Neither the United States Government nor any agency thereof, nor Battefle Memorial Institute, nor any or their employees, makes any warranty, expressed or implied, or assumes any legal liability or responsibility for the accuracy, completeness, or usefulness of any information, apparatus, product, or process disclosed, or represents that its use would not infringe privately owned rights. Reference herein to any specific commercial product, process, or service by trade name, trademark, manufacturer, or otherwise does not necessarily constitute or imply its endorsement, recommendation, or favoring by the United States Government or any agency thereof, or Battelle Memorial Institute. The views and opinions of authors expressed herein do not necessarily state or reflect those of the United States Government or any agency thereof.

\section{PACIFIC NORTHWEST LABORATORY operated by \\ BATTELLE MEMORIAL INSTITUTE for the \\ UNITED STATES DEPARTMENT OF ENERGY under Contract DE-ACO6-76RLO 1830}

Printed in the United States of America
Avaitable from
National Technical Information Service
United States Department of Commerce
5285 Port Royal Road
Springfield, Virginia 22167
NTIS Psice Codes
Microfiche A01
Printed Copy
Pages
$007-125$
$026-050$


PNL-6861

UC-95C

MOBILE ENERGY LABORATORY USE PLAN

April 1989

Prepared for

the U.S. Department of Energy

Federal Energy Management Program

under contract DE-AC06-76RLO 1830

Pacific Northwest Laboratory

Richland, Washington 99352 
MORIIE ENFRGY IABORATORY USE PLAN
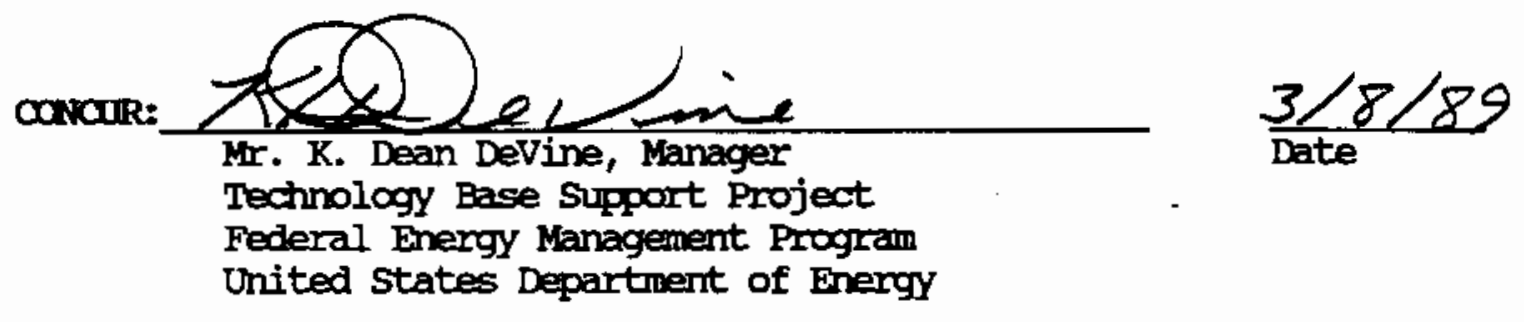

concuR: $\begin{aligned} & \text { anres C Vasulofy } \\ & \text { Mr. James C. Vasiloff, Forces Command } \\ & \text { Executive Agent for Mobile Energy Iaboratory } \\ & \text { Army Energy office } \\ & \text { Office of the Deputy chief of Staff for Iogistics }\end{aligned}$

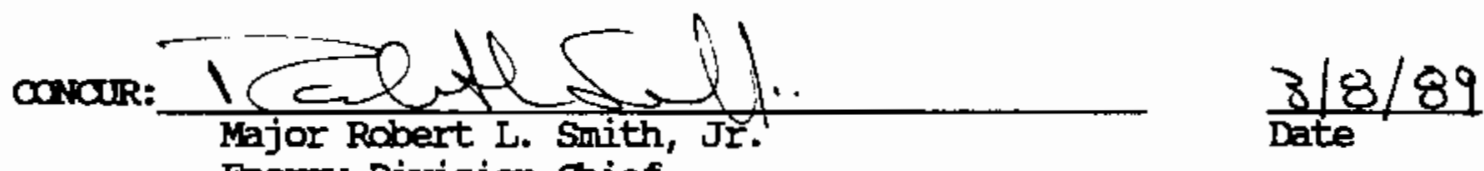
Energy Division Chief

Air Force Engineering and Services center
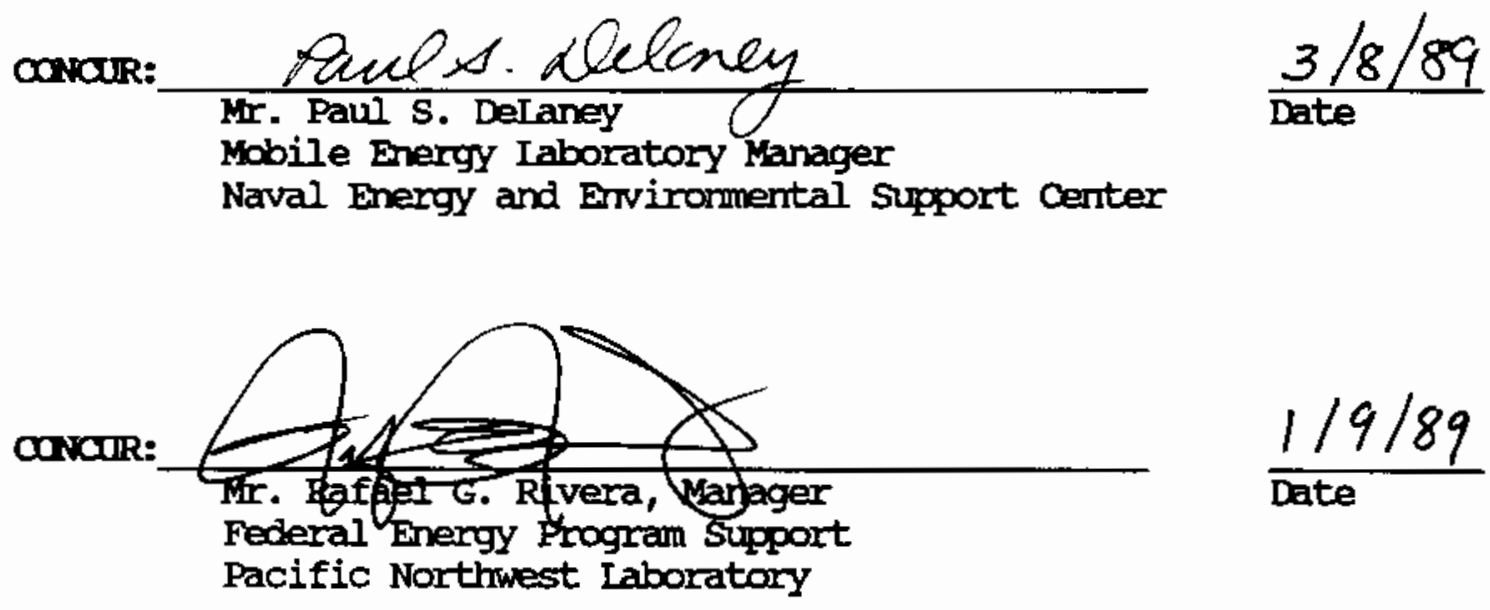

MEL Use Plan

April 1989

SUMMARY

This document provides a framework for the use of four MobiTe Energy Laboratories (MELs) by federal agencies. These laboratories are made available by the U.S. Department of Energy Federal Energy Management Program (FEMP) to measure and analyze the efficiency of on-site energy conversion, distribution, and end-use application. The MELs are customized passenger buses converted to provide transportation and storage of sophisticated energy monitoring, auditing, and analysis equipment. The MELs also provide mobile work space for specially trained engineers and technicians.

One MEL is currently assigned to each of the following agencies: Department of the Army, Department of the Air Force, Department of the Navy, and Department of Energy. Experience over the past five years has indicated the need for centralized MEL administration, application scheduling, test procedure development, user training, and technical oversight. This need is evidenced by increasing requests for MEL use and the economies available by having trained ful1-time MEL operators and near continuous MEL operation. Other evidence suggests that a regional, rather than Departmental, administration can reduce the costs of MEL relocation.

Pacific Northwest Laboratory (PNL) has been tasked to plan for and implement this new framework for MEL use as part of its overall technical support to the FEMP. PNL will maintain the MELs, upgrade their capabilities, and coordinate applications with using agencies. PNL will also provide trained engineers and technicians as needed to work with host facility staff in the identification, conduct, and review of energy use efficiency tests.

Federal agencies wishing to obtain MEL services must contract with the Department of Energy. This MEL Use Plan establishes policy and procedures for Federal agencies. Addenda to this MEL Use Plan are developed for each using agency or Major Command to document specific requirements or exceptions.

This MEL Use Plan will be updated and revised as appropriate. The version number is indicated at the top of each page. Once agreements are in place revisions will only be made with user agency concurrence. Please contact Mr. Richard Mazzucchi (K5-20), Battelle Pacific Northwest Laboratory, P0 Box 999, Richland WA 99352 with any written comments or suggestions. His telephone number is (509) 375-3606. 
MEL Use Plan

April 1989

TABLE OF CONTENTS

Page

1.0 MOBILE ENERGY LABORATORY (MEL) USE POLICY............... 1-1

1.1 INTRODUCTION.................................... 1-1

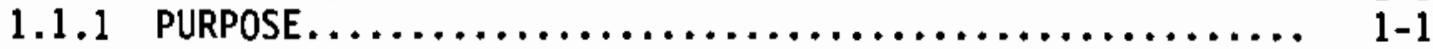

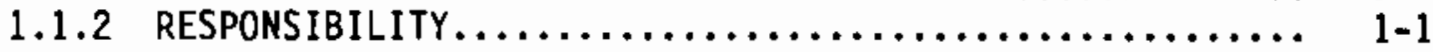

1.2 ASSIGNMENT OF THE MEL............................ $1-1$

1.2 .1 MEL USE COMMITTEE $\ldots \ldots \ldots \ldots \ldots \ldots \ldots \ldots \ldots \ldots \ldots \ldots \ldots, 1-1$

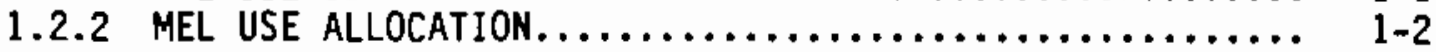

1.3 MANNING OF THE MEL $\ldots \ldots \ldots \ldots \ldots \ldots \ldots \ldots \ldots, \ldots \ldots, 1-2$

1.3 .1 ASSIGNMENT OF PERSONNEL $\ldots \ldots \ldots, \ldots \ldots \ldots, \ldots \ldots \ldots, \ldots, 1-2$

1.3 .2 TRAINING OF PERSONNEL $\ldots \ldots \ldots \ldots \ldots \ldots \ldots \ldots \ldots \ldots \ldots, 1-2$

1.4 ASSIGNMENT OF MEL EQUIPMENT...................... $1-2$

1.5 FUNDING OF MEL OPERATIONS $\ldots \ldots \ldots \ldots \ldots \ldots \ldots \ldots \ldots, 1-3$

$1.5 .1 \quad$ U.S. DEPARTMENT OF ENERGY (DOE) FUNDS $\ldots \ldots \ldots \ldots \ldots \ldots \ldots, 1-3$

1.5 .1 .1 EQUIPMENT REPLACEMENT AND UPGRADES $\ldots \ldots \ldots \ldots \ldots \ldots \ldots, 1-3$

1.5 .1 .2 DEVELOPMENT OF NEW TEST PROCEDURES $\ldots \ldots \ldots \ldots \ldots \ldots \ldots, 1-3$

1.5 .1 .3 MEL OPERATOR TRAINING......................... $1-3$

1.5 .1 .4 OVERALL MEL OPERATIONS MANAGEMENT.................. 1-3

1.5 .2 USING AGENCY FUNDS $. \ldots \ldots \ldots \ldots \ldots \ldots \ldots \ldots \ldots \ldots \ldots, 1-3$

1.5 .2 .1 ADMINISTRATIVE COSTS $\ldots \ldots \ldots \ldots \ldots \ldots \ldots \ldots \ldots \ldots \ldots \ldots \ldots \ldots \ldots \ldots, 1-3$

1.5.2.2 PACIFIC NORTHWEST LABORATORY (PNL) PERSONNEL........... 1-4

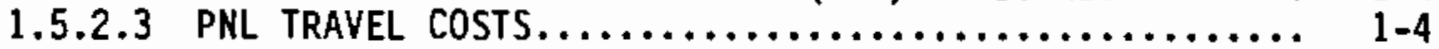

1.5.2.4 MEL RELOCATION AND VEHICLE MAINTENANCE COST......... 1-4

1.5 .2 .5 MEL TEST EQUIPMENT MAINTENANCE $\ldots \ldots \ldots \ldots \ldots \ldots \ldots \ldots, 1-4$

1.5 .2 .6 SPECIAL TEST EQUIPMENT.......................... $1-4$

2.0 RELOCATION OF THE MOBILE ENERGY LABORATORY.............. 2-1

2.1 RELOCATION PLAN..................................

2.2 DRIVER TRAINING............................... $2-1$

2.3 OVER THE ROAD PROCEDURE.......................... 2-1

2.3.1 PRE-TRIP SAFETY INSPECTION....................... $2-1$

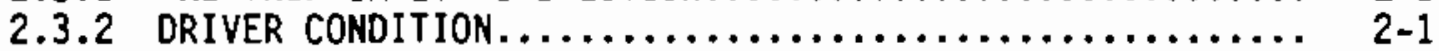

2.3 .3 CHECKPOINT CALLS $. . \ldots \ldots \ldots \ldots \ldots \ldots \ldots \ldots \ldots \ldots, \ldots \ldots \ldots, 2-1$

2.3 .4 TRIP ROUTING $\ldots \ldots \ldots \ldots \ldots \ldots \ldots \ldots \ldots \ldots \ldots \ldots \ldots, 2-1$

2.3 .5 PASSENGERS $\ldots \ldots \ldots \ldots \ldots \ldots \ldots \ldots \ldots \ldots \ldots \ldots \ldots \ldots \ldots, 2-2$

2.3 .6 MEL SECURITY................................... $2-2$ 
MEL Use Plan April 1989

IABLE OF CONTENTS (CONT)

3.0 FACILITY ACCOMMODATIONS AND HOURS OF OPERATION............ 3-1

3.1 ACCOMMODATIONS FOR THE MEL......................... 3-1

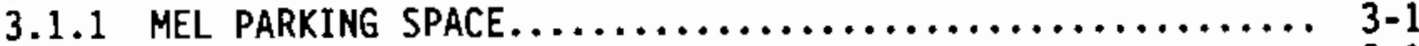

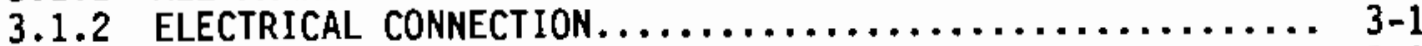

3.1 .3 TELEPHONE ACCESS $. \ldots \ldots \ldots \ldots \ldots \ldots \ldots \ldots \ldots \ldots \ldots \ldots \ldots, 3,1$

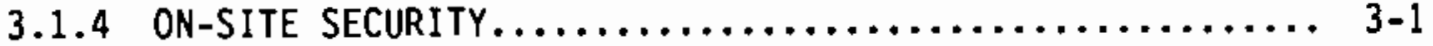

3.2 ACCOMMODATIONS FOR THE MEL PERSONNEL............... $3-1$

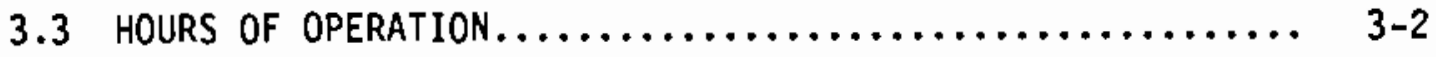

3.4 FACILITY POINT OF CONTACT $\ldots \ldots \ldots \ldots \ldots \ldots \ldots \ldots \ldots, 3-2$

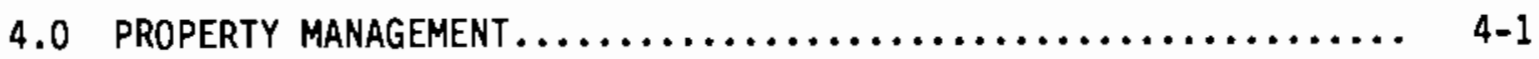

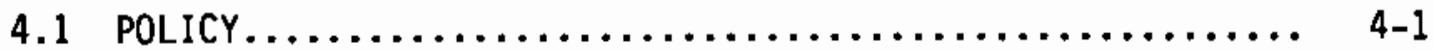

4.2 DOE PROPERTY..................................... 4

4.3 PROPERTY OF OTHERS $. . \ldots \ldots \ldots \ldots \ldots \ldots \ldots \ldots \ldots \ldots \ldots \ldots, 4,1$

4.4 PROPERTY CONTROL CUSTODIAN........................ 4-1

4.4 .1 PROPERTY LOSS OR THEFT........................... 4 4-1

4.4 .2 PROPERTY DAMAGE OR EXCESS $. \ldots \ldots \ldots \ldots \ldots \ldots \ldots \ldots \ldots \ldots, 4,1$

4.5 PROPERTY LOANS OR TRANSFERS.................... $4-1$

4.6 EQUIPMENT INVENTORY $\ldots \ldots \ldots \ldots \ldots \ldots \ldots \ldots \ldots \ldots \ldots \ldots, 4,2$

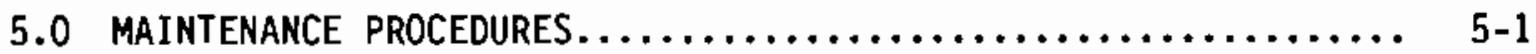

5.1 Maintenance OF THE MEL VEhICLES...................., 5-1

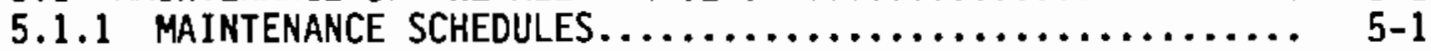

5.1 .2 MAINTENANCE LOGS.............................. $5-1$

5.1 .3 QUALIfied MaintenanCE PERSONNEL $\ldots \ldots \ldots \ldots \ldots \ldots \ldots \ldots, 5-1$

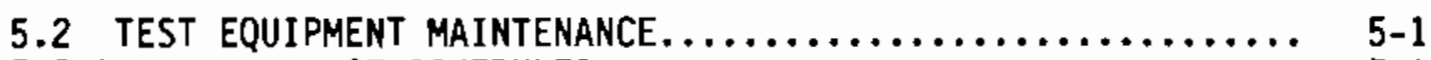

5.2 .1 MAINTENANCE SCHEDULES $\ldots \ldots \ldots \ldots \ldots \ldots \ldots \ldots \ldots \ldots \ldots \ldots, 5-1$

5.2 .2 MAINTENANCE LOGS.............................. $5-1$

5.2 .3 QUALIFIEd MAINTENANCE AND CALIBRATION PERSONNEL....... 5-1 
6.0 TEST IDENTIFICATION................................ $6-1$

6.1 INTRODUCTION...................................

6.2 PURPOSE. $\ldots \ldots \ldots \ldots \ldots \ldots \ldots \ldots \ldots \ldots \ldots \ldots \ldots \ldots \ldots \ldots \ldots \ldots \ldots, 6,1$

6.3 COLLECTION OF UTILITY AND CLIMATE DATA............... $6-1$

6.4 COLLECTION OF FACILITY CHARACTERISTICS DATA........... $6-1$

6.5 DISCUSSIONS HITH FACILITY PERSONNEL,............... $6-1$

6.6 PREPARATION OF A MEL APPLICATION PLAN............... $6-2$

6.7 PREPARATION OF A TEST IDENTIFICATION REPORT........... $6-2$

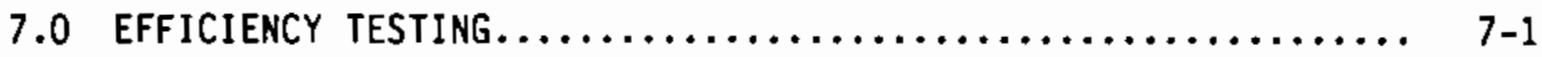

7.1 INTRODUCTION...................................

7.2 TEST PROCEDURE................................ 7-1

7.2 .1 PURPOSE OF TEST $. \ldots \ldots \ldots \ldots \ldots \ldots \ldots \ldots \ldots \ldots \ldots \ldots \ldots, 7-1$

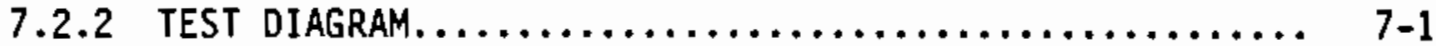

7.2 .3 INSTRUMENT LIST................................ $7-1$

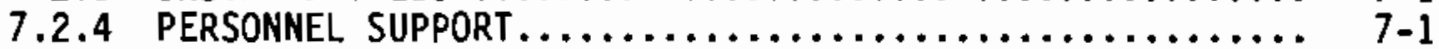

7.2 .5 DATA REDUCTION................................ $7-2$

7.2 .6 TESTING SCHEDULE.................................. $7-2$

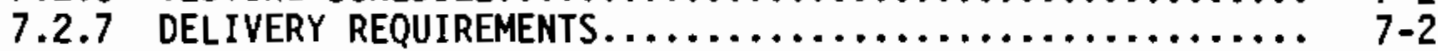

7.2 .8 TESTING COST $. \ldots \ldots \ldots \ldots \ldots \ldots \ldots \ldots \ldots \ldots \ldots \ldots \ldots, 7, \ldots \ldots \ldots, 7,2$

7.2 .9 EXPERIENCES $\ldots \ldots \ldots \ldots \ldots \ldots \ldots \ldots \ldots \ldots \ldots \ldots \ldots, 7,2$

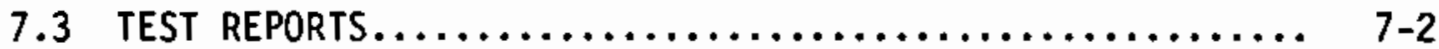

7.3 .1 FORMAT OF REPORTS $\ldots \ldots \ldots \ldots \ldots \ldots \ldots \ldots \ldots \ldots \ldots, 7, \ldots \ldots \ldots, 7,2$

7.3 .2 APPROVAL REQUIREMENT $. \ldots \ldots \ldots \ldots \ldots \ldots \ldots \ldots \ldots \ldots, 7-2$

7.4 TESTING CATALOG.............................. $7-3$

8.0 ADMINISTRATIVE REPORTING $\ldots \ldots \ldots \ldots \ldots \ldots \ldots \ldots \ldots \ldots \ldots, 8,1$

8.1 FIELD OPERATIONS REPORT....................... $8-1$

8.2 FIELD PROGRESS REPORT $\ldots \ldots \ldots \ldots \ldots \ldots \ldots \ldots \ldots \ldots \ldots, 8,1$

8.3 MEL INFORMATION AND UTILIZATION REPORT,........... 8 -1 
MEL Use Plan

Apri] 1989

\subsection{MOBILE ENERGY LABORATORY USE POLICY}

1.1 INTRODUCTION. The Mobile Energy Laboratory (MEL) is equipped for the on-site evaluation of energy use efficiency. Traceable energy use metering and analys is equipment is provided to test the efficiency of energy conversion and distribution systems, as well as the various end-use applications. Specific test procedures are developed for conmon investigations. Specially trained engineers and technicians are provided to conduct tests in a safe and efficient manner with the assistance of host facility staff and contractors. Reports are produced to describe test procedures, results, and suggested courses of action. These reports can be used to justify changes in operating procedures, maintenance efforts, system designs, or energy using equipment. The MEL capabilities can subsequently be used to assess the results of energy conservation projects.

1.1.1 PURPOSE. Four MELs have been configured for use on federal facilities by the U.S. Department of Energy Federal Energy Management Program (FEMP). Although the MELs are the property of the Department of Energy, a MEL is assigned to each of the following federal agencies: 1) Department of the Army, 2) Department of the Navy, 3) Department of the Air Force, and 4) Department of Energy (DOE). This plan recognizes the need for and advantages of centralized administration, test procedure development, and operator training. DOE will assign new equipment and upgrade existing equipment as new capabilities are developed. The equipment and trained technicians will be made available to federal agencies that provide funding for the direct costs associated with MEL use as identified below.

1.1.2 RESPONSIBILITY. With DOE approval, Pacific Northwest Laboratory (PNL) is responsible for MEL maintenance, equipment calibration, test procedure development, and overall on-site/road management and reporting requirements. PNL has existing project management procedures (as documented in the Management Guide) for operating a DOE multi-purpose laboratory and will follow these procedures with respect to the MELs. PNL is managed by the Battelle Memorial Institute under contract to DOE.

1.2 ASSIGNMENT OF THE MEL. PNL will coordinate assignments of all MELs with federal agencies that provide funding support for MEL use (using agencies). Each MEL will be principally assigned to one of four geographic regions of the continental United States. MEL assignments will be made only after a MEL Applications Plan (MAP) is approved. The MAP will indicate the tests to be conducted, the estimated duration of the tests, and the specific logistical and management requirements for each assignment. Information to develop the MAP will be obtained during a physical inspection of the facility by a trained MEL operator.

1.2.1 MEL USE COMMITTEE. The MEL use committee will review all MEL Applications $\mathrm{Pl}$ ans and resolve any scheduling conflicts. Subject to contracting authority this committee is comprised of the following voting members: a U.S. Army representative, a U.S. Air Force representative, a U.S. 
MEL Use Plan

April 1989

Navy representative, and a U.S. Department of Energy representative. A fifth representative of the Federal Energy Management Program will resolve tie votes. A representative of Pacific Northwest Laboratory will serve as executive secretary for this committee. Generally, assignments will follow a screening phase (see Chapter 6: Test Identification) where a site visit is made and readily obtainable data is reviewed. The MEL Use Committee will meet at least twice each year to approve the schedule for MEL applications. Any assignment priority may be superceded on receipt of a directive from any using agency with respect to its authorized MEL allocation. A specific addendum to this plan will address the particular MEL use approval requirements for each using agency or Major Command as applicable.

1.2.2 MEL USE ALLOCATION. Allocation of MEL capabilities to using agencies will be based upon "MEL-months". The number of MEL-months for each using agency will be forecasted for the next twelve months at each MEL Use Committee meeting, and the MELs will be dedicated to each agency in accordance with this allocation and available funding.

1.3 MANNING OF THE MEL. Manpower will be provided for the MELs by PNL. Other organizations may provide MEL staff upon approval of PNL and FEMP management. This approval is contingent upon execution of a MEL Access Agreement, that ensures that the staff members are adequately trained, aware of safety requirements, and responsible for the security and safeguarding of MEL equipment. PNL will maintain equipment inventory control, calibration, and accountability, and perform energy efficiency testing and evaluation on a 40 hour per week basis. Each MEL will have an on-site MEL manager who will identify and conduct tests in association with facility operations and maintenance staff, and others as required.

1.3.1 ASSIGNMENT OF PERSONKEL. Personnel are normally assigned to operate the MEL 40 hours per week. The timing of these hours will be flexible to best coordinate with task requirements. Assignments to a specific facility will typically be for three to eight weeks during any six month period. The personnel assigned to the MEL will have electro-mechanical knowledge and be trained as per Section 1.3.2.

1.3.2 TRAINING OF PERSONNEL. PNL will provide training in the use of MEL capabilities. Each person permanently assigned to the MEL will be given instructions to operate and maintain the vehicle in a safe and road-worthy manner. Specific training with respect to the identification, configuration, and conduct of tests will be provided. Written procedures will be followed and any deviation from these procedures will be approved by PNL management before execution. Properly trained staff from other organizations may use the MEL and equipment with a properly executed MEL Access Agreement.

1.4 ASSIGNMENT OF MEL EQUIPMENT. The scope of some tests may be sufficiently limited that relocation of the MEL may not be necessary, only specific equipment or expertise for installation and analysis may be required. In this event, PNL may ship test equipment and pay travel and labor expenses for 
MEL Use Plan

April 1989

a technician to conduct the specified tests. These expenses will be paid by the requesting agency. This equipment will remain the property of $D O E$ and must be used according to written procedures for approved tests. Such applications of the equipment will be allowed only if the principal capability of the MELs is not impaired.

1.5 FUNDING OF MEL OPERATIONS. There are two sources of funding for MEL operations. The Federal Energy Management Program of DOE provides funds for new MEL equipment, test procedure developments, and overall management. The other source of funding is from the agencies that use the MELs. This is to recover actual costs associated with use of the MELs on their facilities.

1.5.1 U.S. DEPARTMENT OF ENERGY FUNDS. DOE provided funds for the initial development and equipping of the MELs. In the future, DOE funds will be used to upgrade the equipment, develop new test procedures, train MEL operators, and to manage the overall use of the MELs.

1.5.1.1 EQUIPMENT REPLACEMENT AND UPGRADES. DOE will provide funds for replacing obsolete or outmoded equipment. These procurements are coordinated through PNL and Naval Energy And Environmental Support Activity (NEESA).

1.5.1.2 DEVELOPMENT OF NEW TEST PROCEDURES. DOE will provide funds for the development of generic test procedures. If special tests are required by particular agencies, DOE may recover these costs from the benefitting agency.

1.5.1.3 MEL OPERATOR TRAINING. DOE will provide funds for the initial training and certification of MEL operators. If special capabilities are required by particular agencies, DOE may recover these costs from the benefitting agency.

1.5.1.4 OVERALL MEL OPERATIONS MANAGEMENT. DOE will provide funds for overall MEL operations management expenses by PNL. These are management expenses not directly associated with particular using agencies and support coordination of the MELs and the Para 1.5.1.1 through 1.5.1.3 activities.

1.5.2 USING AGENCY FUNDS. PNL will recover actual costs for MEL use by that agency. These costs include administration, direct staff labor and travel, MEL relocation, MEL and equipment maintenance, and expendable supplies.

Estimates of these costs for each MEL assignment will be developed during the screening phase and approved by the using agency before MEL assignment. These estimates will not be exceeded by PNL without prior approval of the using agency and will not exceed the overall funding limits indicated by the using agency. The using agency will reimburse PNL for any equipment loss or damage resulting from negligence on their part.

1.5.2.1 ADMINISTRATIVE COSTS. PNL will recover administrative costs directly associated with each MEL assignment from the using agencies on an actual cost basis. These are costs for MEL test development, MEL assignment planning, and MEL management and accounting. 
MEL Use Plan April 1989

1.5.2.2 PNL PERSONNEL. PNL will maintain a payroll record. Costs will be accumulated on a per assignment basis using a DOE approved project accounting system.

1.5.2.3 PNL TRAVEL COSTS. PNL will recover the costs associated with PNL staff travel and off-site living expenses incurred for each MEL assignment. These costs will be in accordance with joint travel regulations unless otherwise authorized. Every attempt will be made to minimize such costs by optimally routing the MELs, staffing with appropriate personnel, and seeking on-base housing or special long-term accormodations.

1.5.2.4 MEL RELOCATION AND VEHICLE MAINTENANCE COSTS. PNL will recover the costs associated for each MEL relocation and for vehicle maintenance. The vehicles will be maintained in a road-worthy condition. A credit card will be provided for fuel and incidental maintenance (truck stop) requirements. The actual costs associated with each relocation will be charged to the receiving agency. These costs include the labor hours necessary to relocate the MELs and MEL operators. The costs of any major repairs will be pro-rated among the using agencies in proportion to their level of MEL use, unless DOE elects to pay the full cost of any such repairs due to special circumstances.

1.5.2.5 MEL TEST EQUIPMENT MAINTENANCE. PNL will recover the costs associated with maintenance of the MEL test equipment. Any re-calibrations or repairs to the equipment necessary at the conclusion of a MEL assignment will be charged to that assignment. Any non-routine maintenance and calibration expenses will be recovered on a pro-rate basis based upon percentage of total use by each using agency.

1.5.2.6 SPECIAL TEST EQUIPMENT. Any organization may procure special test equipment for assignment and management through the MEL. Costs associated with such equipment administered through the MEL will be borne by the organization that procured the equipment. Any such equipment must be compatible with the DOE assigned test equipment, and may not adversely affect the primary mission of the MELs. 
MEL Use Plan

April 1989

\subsection{RELOCATION OF THE MOBILE ENERGY LABORATORY}

2.1 RELOCATION POLICY. The MELS will be relocated in accordance with an approved MEL APplications Plan. PNL will make arrangements with the host installation staff. A relocation plan will be developed to schedule the necessary staff, ensure the MEL is in a road-worthy condition, and to ensure that the host facility is ready to accommodate the MEL.

2.2 DRIVER TRAINING. MEL drivers will be specially trained to drive this class of vehicle. They will receive special instruction regarding defensive driving practices, vehicle safety inspection, and first-aid from qualified instructors. Each driver of the MEL will have a valid drivers license and will operate the vehicle in accordance with applicable laws and common sense.

2.3 OVER THE ROAD PROCEDURE. The MEL and its equipment will be operated and secured in a manner to prevent damage or loss of equipment. MEL routing will be determined in advance of transit, with specified checkpoints to ensure trouble-free relocation. Written procedures for MEL operation will be followed.

2.3.1 PRE-TRIP SAFETY INSPECTION. The vehicle will be inspected by the driver prior to relocation. A check sheet will be completed by the driver to ensure that the tires are properly inflated and in adequate condition, the fuel and lubrication levels are sufficient, all driving lights and indicators are operational, mirrors are adequate and properly adjusted, windshields are clean, wipers and horn are operational, and that air pressure and braking systems are effective. All equipment will be properly stored or secured during transit.

2.3.2 DRIVER CONDITION. The driver will not operate the MEL if tired, under the influence of substances that may impair driving ability, or otherwise physically or mentally impaired. It is the responsibility of both the driver and escort to ensure that these requirements are met.

2.3.3 CHECKPOINT CALLS. While the MEL is in transit, a contact to the MEL operations center will be made at least once per day. The purpose of this contact will be to monitor trip progress, share information on driving conditions, and to coordinate arrangements.

2.3.4 TRIP ROUTING. General time frames for MEL routing will be obtained from the Rand-McNally (a) United States Mileage and Driving Time Map. Actual routing may deviate from this if necessary, however routing will be by interstate and primary U.S. highway insofar as possible. During periods when inclement weather is possible, the driver will contact authorities to ascertain the condition of the roads to be travelled. Chains will be used when warranted. Excursions of the MEL for personal reasons will not be permitted, however,

(a) Published annually by Rand-McNally \& Company, Chicago, Illinois. 
MEL Use Plan

April 1989

visit time using the support vehicle may be permitted on approval of PNL management.

2.3.5 PASSENGERS. The MEL is not a passenger vehicle. Consequently, no passengers (other than the drivers) shall be transported without management approval unless an emergency or maintenance condition warrants.

2.3.6 MEL SECURITY. While in transit, the MEL will be parked in a well lighted area, if possible. All windows, doors, and access ports will be locked when the vehicle is unattended. Equipment cabinets will be locked to further secure the test equipment. Should the security of the vehicle be violated, the driver will contact police authorities and PNL management as soon as possible. While the MEL is undergoing any required maintenance, the driver will ensure that all equipment is secured. 
MEL Use Plan

April 1989

\subsection{FACILITY ACCOMMODATIONS AND HOURS OF OPERATION}

3.1 ACCOMMODATIONS FOR THE MEL. The MEL is a 44 passenger bus converted to provide working space for the assigned technicians and storage space for sophisticated and expensive test equipment. It is necessary to locate the MEL in a well lighted and secure area with appropriate electrical connections. It is also desirable to provide a telephone line or a nearby telephone contact so that PNL can contact the MEL technicians on a regular basis.

3.1.1 MEL PARKING SPACE. An appropriate location to park the MEL during its stay at the host facility will be selected before a MEL arrives at a host facility. This location will be the base of operations for the MEL effort, so it should be in reasonable proximity to the MEL contact person and facility staff. This location should be well lighted and routinely checked by security personnel. The location should not obstruct normal facility operations.

3.1 .2 ELECTRICAL CONNECTION. The MEL will require a 50 amp, 120 volt electrical connection to be provided by the using facility. Each MEL is equipped with a 100 foot power cord. This connection provides power to operate the MEL interior lights, test and calibration equipment, and space conditioning systems.

3.1.3 TELEPHONE ACCESS. The host facility will provide telephone access without reimbursement from the testing program. The MEL operators will need access to a telephone line on a daily bas is to transmit and receive electronic messages. These messages will transfer instructions from PNL to the MEL operators, $\log$ test progress, and communicate test results. The telephone will also be used for discussions with PNL technical support and management staff. Although it is most desirable to have a phone line physically run to the MEL for connection of the MEL computer, the computer can be transported to an existing line if necessary. The telephone access point should be no greater than 300 feet from the MEL parking space so that a wireless telephone can be used, or the time required to respond to a call will be short.

3.1.4 ON-SITE SECURITY. The MEL will be properly secured from the time it arrives at the host facility until it departs for its next assignment. This security will include the locking of all doors, windows, and equipment cabinets when the MEL is unattended. Also the MEL location shall be well lighted and routinely checked by security personnel. A set of keys for the MEL will be provided to the principal point of contact at the host facility for emergency purposes. The security force will be informed regarding the location and sensitive nature of the MEL equipment, and to ensure that they know who to contact in the event of any unusual activity. If the MEL is parked in a locked storage area, the MEL operators will obtain and return keys for this area on a daily basis.

3.2 ACCOMMODATIONS FOR MEL PERSONNEL. Accommodations for the MEL personne? will be arranged during the screening visit. If the host facility has 
appropriate guest facilities at competitive rates these will be requested. Alternatively, MEL personnel will make arrangements to stay at local moteis. The host facility will make arrangements for the MEL operators to access and leave the host facility and buildings as required.

3.3 HOURS OF OPERATION. The MEL is normally operated on a 40 -hour per week basis. These hours can be scheduled to best coordinate with the host facility staff, and to conduct certain tests during off-hours as appropriate. Any non-normal working hour requirements will be identified and scheduled well in advance of actual need. The MEL operators do not need to be supervised (unless the host facility requires this), however, most tests will not be conducted solo for safety reasons. Compensatory time may be allowed by PNL for emergency or critical scheduling requirements that exceed eight hours per day or 40 hours per week.

3.4 FACILITY POINT OF CONTACT. The host facility will provide a central point of contact for MEL operations. This individual will be kept aware of the activities of the MEL and be responsible for arranging for support staff, building and facility access, and other issues surrounding the MEL activities. A back-up contact person should be identified in the event of vacations, sickness, or travel on the part of the principal contact. 
MEL Use Plan

April 1989

\subsection{PROPERTY MANAGEMENT}

4.1 POLICY. PNL will maintain a property management system consistent with sound business practices, the terms and conditions of DOE prime contracts, applicable laws and regulations, and generally accepted accounting principles. Detailed policies and procedures are contained in PNL-MA-69; Property Management. Property management methods are to be applied to DOE and non-DOE sponsored programs based on applicable contractual requirements.

4.2 DOE PROPERTY. The vehicles and DOE assigned equipment will remain the property of DOE. All property acquired by PNL with DOE funds will remain the property of DOE, unless other contractual arrangements between DOE and the sponsoring agency direct otherwise. Each item will be uniquely tagged as DOE property and carried on appropriate property inventories.

4.3 PROPERTY OF OTHERS. Property furnished to PNL by another party, including non-DOE government agencies, and all property purchased by PNL in connection with a contract with another party where such party pays the full cost of the property, will remain the property of the purchasing party. This property will be so tagged (property of others) and maintained on separate inventory for each party.

4.4 PROPERTY CONTROL CUSTODIAN. A Property Control Custodian at PNL will maintain responsibility for all property assigned to the MELs. This custodian will implement a system as needed to ensure the availability, maximum use, control, and accountability of assigned capital property to include equipment assigned by using agencies. Equipment record responsibility may be redelegated by the Property Control Custodian to a Property Representative upon notification to the PNL Property Management and Account ing Office.

4.4.1 PROPERTY LOSS OR THEFT. The MEL operator or other responsible party will inform the Property Control Custodian of any missing property. The Property Control Custodian will then immediately report suspected theft of any property to the Project Manager, PNL Security, and the Property Management and Accounting Office. If loss or theft of property is involved, a Missing Plant and Equipment Report will be prepared by the cognizant MEL operator or other responsible party.

4.4.2 PROPERTY DAMAGE OR EXCESS. A Property Disposal Request will be prepared to document property damage or to dispose of outdated property of DOE or other sponsors. If repair or updating costs exceed the purchase price of new equipment, such damaged or outdated equipment will be excessed and removed from the property books by the Property Control Custodian.

4.5 PROPERTY LOANS OR TRANSFERS. Prior DOE approval will be required for any transfer or loan of DOE owned equipment assigned to PNL to any individual or organization outside PNL except to suppliers under contract to PNL. In most instances, any equipment will remain the property of $\mathrm{PNL}$, and consequently 
PNL staff must ensure that any loaned equipment is used in a safe manner and properly secured during the term of any such loan.

4.6 EQUIPMENT INVENTORY. All equipment will be inventoried by the Property Control Custodian at the time of transfer to, or procurement by, PNL. The equipment will be tagged with a unique property number, and descriptive information including any serial numbers will be logged in the appropriate inventory system. This inventory will be maintained so as to be immediately updated upon any equipment transfer. This inventory will also log equipment use and calibration schedules to ensure that equipment is calibrated or replaced as necessary. MEL operators will sign for inventory before each assignment and will advise the Property Control Custodian of all equipment transfers that occur during each assignment. 
MEL Use Plan

April 1989

\subsection{MAINTENANCE PROCEDURES}

5.1 MAINTENANCE OF THE MEL VEHICLES. PNL will be responsible for the proper maintenance of the MEL vehicles to ensure that they can be used in a safe and efficient manner. PNL will maintain a maintenance log for each vehicle indicating the necessary periodic maintenance schedules and a diary of maintenance actions. Maintenance costs will be paid by the using agencies in proportion to actual use and mileage.

5.1.1 MAINTENANCE SCHEDULES. PNL will develop (or adopt) a maintenance schedule for each MEL vehicle that indicates the present condition, periodic maintenance requirements, dates, descriptions, and costs of maintenance efforts.

5.1.2 MAINTENANCE LOGS. PNL will maintain a system that tracks maintenance actions and requirements to ensure that periodic maintenance is conducted according to miles travelled or time since last action. These logs will also track maintenance costs and billings to particular using agencies.

5.1.3 QUALIFIED MAINTENANCE PERSONNEL. PNL wi11 ensure that all vehicle maintenance is done by qualified mechanics, and that vehicles are properly inspected and road tested following any major repairs.

5.2 TEST EQUIPMENT MAINTENANCE. PNL will identify periodic maintenance and calibration requirements for all test equipment, and maintain a log indicating the maintenance schedules and actions. Spare equipment will be procured to ensure that adequate test equipment is available for use while any periodic off-site maintenance or calibration is carried out.

5.2.1 MAINTENANCE SCHEDULES. PNL will implement a maintenance and calibration schedule for each major piece of test equipment. Presently this includes the steam flow computers and sensors, the electrical metering equipment, and the chemical analysis equipment. As other test equipment is added, a specific maintenance schedule will be developed as appropriate or recommended by the equipment manufacturer.

5.2.2 MAINTENANCE LOGS. PNL will maintain a system that tracks maintenance and calibration actions and requirements to ensure that periodic maintenance and calibration is carried out as necessary. The costs associated with such maintenance and calibration will be tracked as well to pro-rate such expenses to the various users based upon a percentage of use bas is.

5.2.3 QUALIFIED MAINTENANCE AND CALIBRATION PERSONNEL. PNL will ensure that any maintenance or calibration of test equipment is carried out by qualified personnel. Equipment calibrations will be conducted so as to be traceable to appropriate standard sources. 

MEL Use Plan

April 1989

\subsection{TEST IDENTIFICATION}

6.1 INTRODUCTION. A protocol for the screening of candidate MEL applications is developed to ensure the cost-effectiveness of MEL use and to prepare advance plans for each MEL assignment. This screening will involve the collection and analys is of readily obtainable data regarding the energy consumption and general characteristics of the facility to be studied. As part of this preliminary analysis, a site visit will be scheduled to review this information, as well as other data and studies developed by the facility staff and contractors. An initial set of tests to be conducted will be developed, and an estimate of costs and support requirements will be prepared. A MEL Application Plan will be developed for approval by the using agency and facility contacts. This plan will identify the recommended applications of the MEL for each assignment.

6.2 PURPOSE. The test identification exercise makes use of readily obtainable data to develop the context for MEL applications, and to identify particular apparent opportunities for improving energy use efficiency. Typically, several years of past utility billing records are analyzed in conjunction with climate data to gain an appreciation of the relative importance of facility heating and cooling systems. Then during a site visit additional information is collected to better understand or confirm this appreciation, and to develop additional information to focus MEL applications. Depending upon the availability of data and the size of the facility, this effort may require from 5 to 15 person-days of effort. At the end of this phase, a detailed MEL Application Plan is completed that outlines the tests to be conducted, the tentative schedule of the tests, the costs of the tests, and the host facility support staff requirements.

6.3 COLLECTION OF UTILITY AND CLIMATE DATA. Information regarding the use of various fuels over the past three years will be obtained from the host installation, servicing utilities, or other identified sources. Concurrent weather data will be obtained from the National Oceanic and Atmospheric Administration (NOAA) and the National Weather Service to conduct an analys is of the dependency of energy use on outdoor temperature. This will reveal the relative importance of baseloads versus heating and cooling system loads.

6.4 COLLECTION OF FACILITY CHARACTERISTICS DATA. During the initial site visit by the MEL staff, easily obtained information regarding the characteristics of the host facility will be assembled. This includes the areas of different building types, the types and condition of energy conversion and distribution systems, and any studies pertaining to energy conservation opportunities.

6.5 DISCUSSIONS WITH FACILITY PERSONNEL. Ideas for energy conservation measures and useful tests will be discussed with the facility personnel to become aware of prior, ongoing, or planned efforts. Then a preliminary list of appropriate tests will be developed and visits will be made to the various 
MEL Use Plan April 1989

testing sites to evaluate the appropriateness of the test and to estimate the level of effort needed to carry out the tests.

6.6 PREPARATION OF A MEL APPLICATION PLAN (MAP). Following a site visit and review of available data, a detailed MAP is developed to identify the cost, duration, and schedule of MEL activities at the host facility. This information is reviewed and approved by PNL management, the host facility representative, and the using agency before further work is pursued. An electronic mail system has been established to expedite the reviews on the part of PNL management and using agencies.

6.7 PREPARATION OF A TEST IDENTIFICATION REPORT. A brief report will be prepared summarizing the results of the screening exercise and any MAPs resulting from it. This report will be provided to the host facility, the using agency, and FEMP to document the efforts and to ensure that all parties understand the scope and context of each MEL assignment. 
MEL Use Plan

April 1989

\subsection{EFFICIENCY TESTING}

7.1 INTRODUCTION. Each of the testing capabilities of the MEL will be documented in detailed Test Procedures. This will help ensure that the test results are accurate, comparable, and repeatable. The procedures will be complete, providing an explanation of the applicability and purpose of the test, complete testing diagrams, testing procedures, analys is methods and a detailed requirements list. These procedures for existing MEL capabilities will be developed as soon as possible and added capabilities will have operational testing procedures developed as soon as developmental tests are completed.

7.2 TEST PROCEDURE. The Test Procedures are intended to be useful guidelines. They will spell out the applicability of the tests and the expected impacts on existing systems. This will assist site personnel in deciding the applicability and timing for each proposed application. The required site support, including personnel and temporary operational modifications will be identified. Procedures for verifying acceptable test progress, identifying problems, and termination of unsuccessful efforts are a part of each procedure.

7.2.1 PURPOSE OF TEST. This will be a straightforward and simple expression of the reason for the test and the use of the results. The statement will focus to the primary purpose and should be limited to a single paragraph. Secondary impacts from the test results will be briefly covered in supplemental paragraphs.

7.2.2 TEST DIAGRAM. For each test a complete generic test diagram, showing preferred location of sensors and supporting instrumentation, will be developed and maintained. Specific identification of the test equipment types will be supplied. The diagrams for the equipment or systems to be tested will be complete but generic and well labeled for ease of use. Additional diagrams with optional sensor placements will be developed as their need becomes clearer.

7.2.3 INSTRUMENT LIST. The tests will each require specific classes of instrumentation and test equipment. The individual procedures will include a complete list showing all the required items. If individual devices are range or size limited, then the list will indicate the need for that additional piece of information for the specific application, (such as pipe size, or amp rating).

7.2.4 PERSONNEL SUPPORT. Each using facility is expected to supply support staff since the MEL is not staffed with the crafts and technical personnel for complete operation. The MEL operators will also require time to consult with the facility energy coordinator and/or the energy engineers. The specific support requirements will be estimated in the MEL Application Plan. This plan will be provided to the host facility contact at least one month prior to the need for support so that necessary arrangements can be made. 
MEL Use Plan

April 1989

7.2.5 DATA REDUCTION. The tests will usually result in the collection of data that must be processed or reduced to provide the results. Specific procedures for this data reduction, including methods for data verification and reasonableness checks will be supplied in each test procedure.

7.2.6 TESTING SCHEDULE. A standard form and procedure will be included that identifies the expected impact of the tests on standard operations and details an expected test schedule. This schedule will include an allowance period for obtaining any special test equipment, the assembly of the test apparatus, the installation of the test equipment, the verification of the installation, the collection of test data, the reduction of test data, preparation of the test report, and removal of equipment. Those elements of the schedule which are most uncertain will be specifically identified and time ranges supplied. Any component of the test which would impact standard operations at the site will be highlighted.

7.2.7 DELIVERY REQUIREMENTS. A standard test result delivery sheet will be a part of each procedure. It will fully identify the equipment tested, the date(s) of the tests, and a summary of the approved test report and recommendations. At the conclusion of the test the report will be delivered to the main site contact and others as required and indicated in the addendum.

7.2.8 TESTING COST. A standard cost estimating sheet will be included in each test procedure. For the elements of the procedure that are site specific, ranges will be supplied along with reconmendations on how to complete the form. Whenever possible, specific expressions of hours and current dollars will be used.

7.2.9 EXPERIENCES. Applications of test procedures in the real world of ten result in unanticipated problems. To capture some of the experience of the field activities, a special section of each procedure will be provided to include brief statements of particular instances of the unexpected. The test procedures will then be reviewed and expanded/updated as appropriate.

7.3 TEST REPORTS. Each test will be documented by a test report, the contents and format of which will be outlined prior to the test.

7.3.1 FORMAT OF REPORT. A specific report format, based on the statement of the test purpose, will be developed for each test (reference MEL Test Catalog). It is expected that each format will follow a standard outline for all MEL tests. Sound laboratory practices will be followed, with all test equipment and tested apparatus fully identified. References to notebooks and other references will be specific and traceable. The results of the test and recomnendations for correcting identified system problems or deficiencies will be identified.

7.3.2 APPROVAL REQUIREMENT. The test reports will be submitted to the host facility under the PNL representative signature. The reports will be reviewed by PNL management prior to delivery for quality assurance purposes. Copies 
MEL Use Plan

Apri1 1989

of these reports will be distributed to other representatives of the using agency as directed in an addendum to the plan.

7.4 TESTING CATALOG. Copies of each of the test procedures developed for the MEL will be maintained in a file on each MEL with the master catalog maintained at PNL. Examples of completed testing reports following the detailed procedures will also be maintained. Adequate copies of test forms and other required documentation will be maintained on each MEL. It is expected that electronic versions of the catalog and forms will be the most often used versions, but hard copy will also be maintained. The master version of this testing catalog will be maintained at PNL. The field versions (MEL) will be treated as controlled documents. This will help ensure that each test is performed using the most current test procedure. Existing PNL controlled document procedures will be applied. 


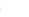


MEL Use Plan

April 1989

\subsection{ADMINISTRATIVE REPORTING}

8.1 FIELD OPERATIONS REPORT. A report will be generated by each active MEL operator each week. This report will be written using a standard format on the personal computer provided on each MEL. The report will be electronically communicated to PNL management by Wednesday of the week following the report period. This report will contain information on the tests in progress, tests completed, and planned activities for the next reporting period. Any equipment damage or calibration issues will be specifically noted. Finally, the report will include labor and other cost information needed to track project costs.

8.2 FIELD PROGRESS REPORT. This report will be prepared by PNL management on a monthly basis to formally report project progress to FEMP and the using agency. These reports will be delivered by the end of the month following the reporting period. These reports will provide information regarding progress made during the period, variance from the plan if any, and planned progress for the next reporting period. Costs will be reported according to the various cost elements identified in Section 1, and charted to indicate planned versus actual expenditures.

8.3 MEL INFORMATION AND USE REPORT. This report will be prepared by PNL management on a quarterly bas is to summarize all MEL applications, developments, and test results. This report will be distributed to the various participating agencies and other interested parties to keep them abreast of MEL activities and capabilities. All MEL operators will receive this report to coordinate their efforts and to benefit from each others experience. This report will not include detailed costs or progress tracking, as this information is communicated to each using agency with respect to their applications in the monthly Field Progress Reports. 
MEL Use Plan

ApriT 1989

ADDENDUM 1

\section{FORCES COMMAND}

1.2 ASSIGNMENT OF THE MEL. The FORSCOM Energy Office will act as the Headquarters DA Executive Agent for the MEL and approve MEL assignments. These assignments will be based upon requests and information from FORSCOM facility managers, and other DA Major Commands (MACOMS). Request for MEL assignment except for FORSCOM installations should initially go to PNL with information copies to Headquarters DA Energy Office and the DA Executive Agent. Once an appropriate contract is in place, PNL will prepare MEL Application Plans for using agency approval. PNL will then work directly with the facility contacts to arrange for MEL delivery, test equipment deployment, data collection, and analysis, and reporting.

1.2.1 MEL USE COMMITTEE. The designated DA Executive Agent for MEL applications is Mr. James C. Vasiloff (404) 362-7148, Commander FORSCOM, FCEN-RDO/Energy, Fort McPherson, GA 30330-6000. Mr. Vasiloff will serve on the MEL Use Committee as representative of the Department of the Army. The Army Energy Office is the final authority for scheduling use of the DA MEL. DA will give FORSCOM 90 days to comply when

use scheduling authority is invoked.

1.5.2 USING AGENCY FUNDS. FORSCOM invoices identifying costs by installation will be submitted to Mr. Vasiloff on a monthly basis for reimbursenent for authorized MEL activities for FORSCOM installations. Invoices for other DA applications will be delivered to the cognizant individual as identified in the using agency's contract agreement.

7.3.2 APPROVAL REQUIREMENT. Copies of all completed test reports will be delivered to $\mathrm{Mr}$. Vasiloff for review and distribution as appropriate. PNL will also provide copies of these reports to the host facility contacts. and the FEMP program manager.

8.1 FIELD OPERATIONS REPORT. Copies of the Field Operations Report will be delivered to Mr. Vasiloff through the FEMP Program Office by the end of the month following the reporting month.

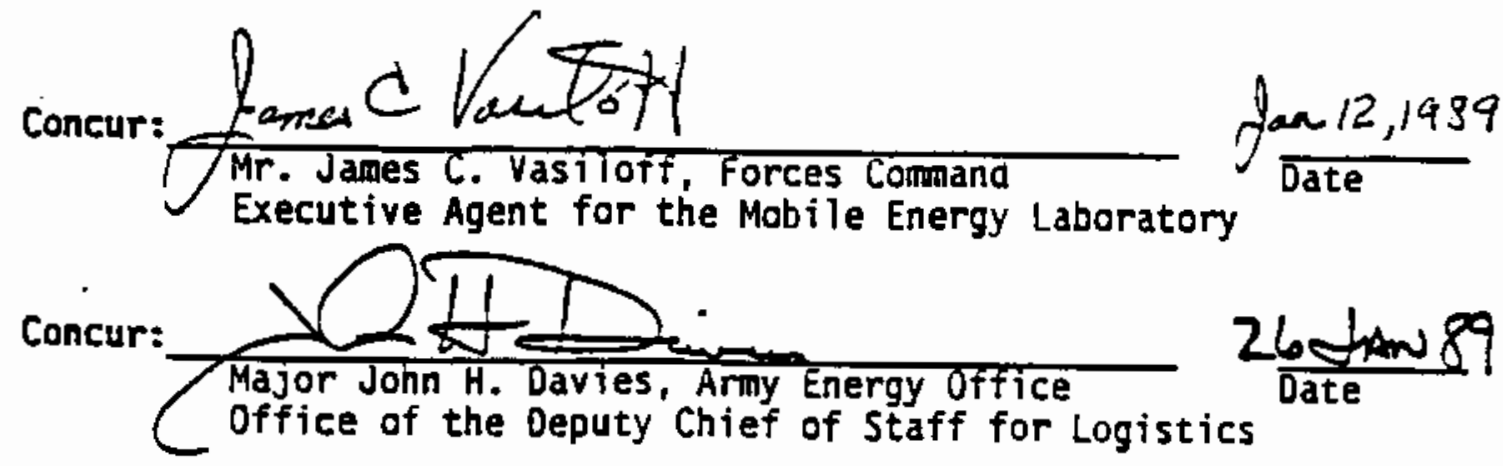





\section{DISTRIBUTION}

No. of

Copies

OFFSITE

10 DOE/Office of Scientific and Technical Information

10 D. DeVine

DOE Federal Energy Management Program

Forrestal Building, CE-116 1000 Independence Avenue, SW Washington, DC 20585

25 J. Vasiloff

Commander, Forces Command ATTN: FCEN-RDO/J. Vasiloff Executive Agent for DA MEL Fort McPherson, GA 30330-6000

10 R. Smith

U.S. Air Force Engineering and Services Center Tynda11, FL 32403

10

P. Delaney

Naval Energy and Environmental Support Activity

Code 111E, Building 1163

Port Hueneme, CA 93043
No. of

Copies

ONSITE

DOE Richland Operations Office

D. L. Sours/A5-90

D. R. Segna/A5-90

38 Pacific Northwest Laboratory

B. A. Garrett/K6-54

B. M. Johnson $/ K 5-12$

J. P. Kohlman/K6-55

R. P. Mazzucchi (20)/K2-51

G. B. Parker $/ \mathrm{K} 5-20$

B. D. Peterson (5)/K5-20

R. G. Rivera/K6-69

T. J. Secrest/K5-20

R. F. Szydlowski/K5-20

Publishing Coordination

Technical Report Files (5) 


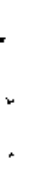

